\title{
Detritus dynamics in the seagrass Posidonia oceanica: elements for an ecosystem carbon and nutrient budget
}

\author{
M. A. Mateo*, J. Romero \\ Departament d'Ecologia, Universitat de Barcelona, Diagonal 645, E-08028 Barcelona, Spain
}

\begin{abstract}
Leaf decay, leaf litter export, burial in belowground sinks, and respiratory consumption of detritus were examıned at 2 different depths in a Posidonia oceanica (L.) Dellle meadow off the Medes Islands, NW Mediterranean. At $5 \mathrm{~m}$, the amount of exported leaf litter represented carbon, nitrogen and phosphorus losses of 7,9 and $6 \%$ of the plant primary production, respectively. About $26 \%$ of the carbon produced by the plant in 1 yr was immobilized by burial in the belowground compartment, i.e. as roots and rhizomes. Annual nitrogen and phosphorus burial in the sediment was 8 and $5 \%$ of total $\mathrm{N}$ and $\mathrm{P}$ needs, respectively. Respiratory consumption (aerobic) of carbon leaf detritus represented $17 \%$ of the annual production. An additional, but very substantial, loss of carbon as very fine particulate organic matter has been estimated at ca $48 \%$. At $13 \mathrm{~m}$ the pattern of carbon losses was sinular, but the lesser effect of wave action (relative to that at $5 \mathrm{~m}$ ) reduced exportation, hence increasing the role of respiratory consumption. Data on carbon losses indicated that only a small part of the plant production was actually available to fuel the food web of this ecosystem. Total nutrient losses were in the range of 21 to $47 \%$ of annual needs. From differences found in $\mathrm{N}$ and $\mathrm{P}$ concentrations between living and dead tissues, it is suggested that important nutrient recycling (50 to $70 \%$ ) may be due either to reclamation or to leaching immediately after plant death.
\end{abstract}

KEY WORDS: Nitrogen Phosphorus Sink - Export - Respiratory consumption

\section{INTRODUCTION}

Seagrass ecosystems are known to be highly productive, and estimates of primary production have been repeatedly achieved (Duarte 1989). In contrast, information on the fate of this production is scarce. In general, grazing on the standing seagrass leaves is low to moderate (Zieman et al. 1979. Thayer et al. 1984, Nienhuis \& Groenendijk 1986, Mann 1988), and most of the seagrass tissues enter the marine food webs as detritus (Benner et al. 1988, Mann 1988). Processes affecting detritus are thus crucial to the understanding of the carbon and nutrient budgets at the ecosystem level. These processes include: (1) detritus production, i.e. leaf fall; (2) leaf litter decay, including both mechanical

- Present address: CEMO-NIOO, Vierstraat 28, 4401 EA Yerseke, The Netherlands. E-mail: mateo@cemo.noo.knaw.nl fragmentation and microbial and faunal consumption; (3) leaf litter export outside the system; and (4) burial of dead organic matter in the sediment. Some of these aspects have been independently assessed for several seagrass species, but, as far as we know, integrative carbon and/or nutrient budgets obtained through concurrent studies of all of them have never been attempted (see Hemminga et al. 1991).

The amount and variability of primary production of the Mediterranean species Posidonia oceanica is well documented (Alcoverro et al. 1995, and references therein), indicating a substantial contribution of this species to the organic supply in neritic waters. Grazing represents a small part of carbon losses (Ott \& Maurer 1977. Zupo \& Fresi 1984, Francour 1990, Mazzella et al 1992. Cebrián et al, 1996), and it seems that the food webs associated with the $P$. oceanica ecosystem are only in minor part fueled by organic carbon produced 
by the seagrass itself, as derived from stable carbon isotopic ratio values (Dauby 1989).

In previous works, some aspects of the detritus dynamics were investigated: litter production variability and export rates (Pergent et al. 1994), rates of litter decay and export (Romero et al. 1992, Pergent et al. 1994), respiratory and mechanical components of leaf detritus decay (Mateo \& Romero 1996) and carbon and nutrient burial in the sediment (Romero et al. 1992, 1994, Mateo et al. 1997); however, the lack of spatial coherence of the data presented in these works prevented the integration of all of them into a single carbon and nutrient budget. In the present paper, and from a totally new and spatially coherent data set, we evaluate the contribution of these processes (i.e. litter decay, litter export, and burial in the sediment) to the carbon and nutrient losses of the Posidonia oceanica ecosystem, with the final goal being to provide data for the understanding of element budgets of this seagrass ecosystem.

\section{MATERIAL AND METHODS}

Study site. Sampling was carried out in the seagrass meadow off the Medes Islands, Gerona, Spain (NW Mediterranean; $42^{\circ} 03^{\prime} \mathrm{N}, 3^{\circ} 14^{\prime} \mathrm{E}$ ), extending from 3 to $15 \mathrm{~m}$ depth. Two stations were chosen, one at $5 \mathrm{~m}$, near the upper limit of the plant distribution, where the meadow has a density of ca 500 shoots $\mathrm{m}^{-2}$, and one at $13 \mathrm{~m}$, close to the lower limit, where the meadow is much sparser with ca 100 shoots $\mathrm{m}^{-2}$ Additional data on this meadow can be found in Romero $(1985,1989)$, Alcoverro et al. (1995), and López et al. (1995).

Leaf litter decay. Decay rates were evaluated using litter bag experiments. A series of mesh bags containing $30 \pm 0.5 \mathrm{~g}$ of fresh senescent material were placed. under the foliar canopy at 5 and $13 \mathrm{~m}$ depth. Mesh size was $1 \mathrm{~mm}$, which is the most common value used (e.g Harrison 1989). Bags were collected in triplicate after 3 wk, 4 wk and 2, 3,6, 9 and 12 mo of incubation. The contents of the bags were washed with tap water, dried at $70^{\circ} \mathrm{C}$ until constant weight and then weighed. Subsamples were taken for elementary analysis.

The weight loss observed in the litter bags, and therefore the inferred decay rates, includes both respiratory consumption and mechanical fragmentation (Mateo \& Romero 1996) To assess the extent of the respiratory componen.t, detritus respiration of coarse litter (>0.8 cm, see below) was measured seasonally. Samples were collected by hand in 8 sampling missions from May 1990 to July 1991 Samples were gently washed in seawater immediately after collection to remove the sediment, then transported in a cool box to the laboratory, and processed within $4 \mathrm{~h}$ after sampling
Oxygen uptake was measured by incubating the detritus in $25 \mathrm{ml}$ stoppered serum vials. Five to six pieces of blade tissue, each of around $2 \mathrm{~cm}^{2}$ (about $100 \mathrm{mg}$ dry weight), were placed into the vials and $10 \mathrm{ml}$ of filtered $(0.2 \mu \mathrm{m}$ Nucleopore filter) seawater were added, leaving about $15 \mathrm{ml}$ of head-space. The vials were incubated in the dark at 15 and $30^{\circ} \mathrm{C}$ for $48 \mathrm{~h}$; 3 replicates were used for each experimental condition. Blanks in both aerobic and anaerobic conditions were incubated to take into account the activity of the incubation medium, but changes in $\mathrm{O}_{2}$ or $\mathrm{N}_{2}$ after the incubation periods were never observed. Oxygen depletion in the head-space was then measured using gas chromatography (Kaplan et al. 1979, López et al. 1995, Mateo \& Romero 1996).

Parallel incubations using the same protocol but under anoxic conditions were performed to measure nitrate respiration. Anoxia was achieved by bubbling helium into the vials for 15 to $20 \mathrm{~min} . \mathrm{N}_{2}$ in the headspace was measured by gas chromatography (Kaplan et al. 1979).

Oxygen uptake by fine litter (between 0.1 and $0.8 \mathrm{~cm}$, see below) was measured on samples collected by suction. Five replicates of ca $100 \mathrm{mg}$ of fine leaf litter were incubated as described above. All experimental conditions were exactly the same as for the aerobic incubations

After the incubations, the detritus was dried (at $70^{\circ} \mathrm{C}$ until constant weight) and weighed.

Respiration rates at field temperature were estimated using the following expressions (Jørgensen \& Sorensen 1985):

$$
\begin{gathered}
r=\ln \left(\frac{R_{15}}{R_{30}}\right) \cdot \frac{1}{30-15} \\
R_{T}=R_{30} \cdot \mathrm{e}^{|r(30-T)|}
\end{gathered}
$$

where $R_{r}$ is the oxygen uptake at temperature $T, R_{15}$ and $R_{30}$ are the oxygen uptake at 15 and $30^{\circ} \mathrm{C}$, and $r$ is the rate of variation of oxygen uptake with temperature.

$Q_{10}$ was estimated as

$$
Q_{1 n}=\left(\frac{R_{T_{1}}}{R_{T_{2}}}\right)^{\frac{10}{T_{1}-T_{1}}}
$$

(Valiela 1984)

where $R_{T_{1}}$ and $R_{T_{2}}$ are the respiration rates at $T_{1}\left(30^{\circ} \mathrm{C}\right)$ and $T_{2}\left(15^{\circ} \mathrm{C}\right)$, respectively.

Water temperature was obtained monthly at the site (5 and $13 \mathrm{~m}$ stations; Romero 1985).

To evaluate the contribution of detritus respiration to the carbon losses of the ecosystem, respiratory rates in $\mathrm{ml}$ of $\mathrm{O}_{2}$ or $\mathrm{N}_{2} \mathrm{~g}^{-1}$ dry wt $\mathrm{h}^{-1}$ were converted to carbon mineralization rates in $\mathrm{mg}$ of $\mathrm{C} \mathrm{g}^{-1}$ dry wt $\mathrm{h}^{-1}$, assuming 1:1 $\mathrm{O}_{2} / \mathrm{C}$ and $1: 2.5 \mathrm{~N}_{2} / \mathrm{C}$ molar quotients (Elliot \& Davidson 1975 and Froelich et al. 1979, respectively) Carbon consumption per unit surface was obtained 
using seasonal data of detritus standing stocks (coarse and fine fractions; see below).

A rough estimate of associated $\mathrm{N}$ and $\mathrm{P}$ losses was achieved using $\mathrm{C} / \mathrm{N}$ and $\mathrm{C} / \mathrm{P}$ ratios of detritic material.

Leaf litter export. Leaf litter export rates were estimated by comparing observed stock values to the expected ones under the hypothesis of zero export (Romero et al. 1992, Pergent et al. 1994)

To estimate leaf litter standing stocks, sampling was performed using a suction device as described in Pergent et al. (1991), aspirating inside a $35 \times 35 \mathrm{~cm}$ quadrat and to a depth of 2 to $4 \mathrm{~cm}$ inside the sediment. At each sampling event, 3 replicates were taken at random over an area of ca $100 \mathrm{~m}^{2}$ at both 5 and $13 \mathrm{~m}$ stations. Sampling was performed seasonally, with a total of 7 sampling events between October 1988 and May 1990

Sediment was immediately washed off the samples with tap water and all coarse materials coming from belowground parts discarded. The rest was sorted as in Romero et al. (1992) into coarse $(>0.8 \mathrm{~cm})$ and fine litter fractions $(0.1$ to $0.8 \mathrm{~cm})$. The coarse fraction consisted of leaf blades in different decomposition stages, while the fine fraction was much more heterogeneous, including leaf debris, dead roots, dead rhizomes, macro- and meio-fauna, and algae. In some subsamples of the fine litter, the foliar debris was separated from the rest.

Each fraction was weighed after drying at $70^{\circ} \mathrm{C}$ until constant weight and subsamples kept for elementary analysis.

The expected litter stocks under the hypothesis of zero export were computed as:

$$
L_{1}^{\prime}=F_{1} \cdot \mathrm{e}^{\left(-k \cdot \frac{1}{2}\right)}+L_{1-t} \cdot \mathrm{e}^{(-k t)}
$$

where $L^{\prime}$ is the predicted litter stock at time $i, F_{i}$ is the weight of leaf material fallen between times $i-t$ and $i$ (from Alcoverro et al. 1995), $t$ is the time interval between consecutive samplings, $k$ is the decay rate and $L_{1-}$ is the observed litter stock at time $i-t$. To compute $F_{1}$, we assumed that most of the leaf losses are due to leaf fall; this assumption is supported by the low grazing pressure at the considered sites. Cebrián et al. (1996) evaluated the consumption by macro-herbivores at $5 \mathrm{~m}$ to be less than $5 \%$, and macro-grazers are usually absent at $13 \mathrm{~m}$ (Alcoverro et al. 1997). Even in the case of a significant consumption, the low assimilation rate of herbivores would result in an additional input to the fine litter fraction. Moreover, we used only leaf production (i.e. excluding epiphytes), since signif icant amounts of epiphytes, except some encrusting species of Rhodophyceae, have never been observed in leaf litter, probably because they detach soon after leaf abscission.
Export rate $\left(E_{l}\right)$ is computed as:

$$
\begin{gathered}
E_{1}=L_{1}^{\prime}-L_{1} \\
\text { (in g dry wt m }{ }^{-2} \text { interval between samplings }{ }^{-1} \text { ) }
\end{gathered}
$$

Export rates of carbon, nitrogen and phosphorus were estimated as the product of $E$, and the nutrient or carbon concentration of the leaf litter in the considered time interval.

Burial in the sediment. Belowground biomass and detritus are formed by roots, rhizomes and the sheaths of old leaves which remain attached to the rhizome after leaf fall. Decay of these materials is practically negligible, at least on a mid-term basis (i.e. decades, see Romero et al. 1994 and Mateo et al. 1997), and only a small weight loss has been reported for some leaf sheaths exposed to water before being buried in the sediment (Romero et al. 1992). To evaluate the amount of dry matter and associated C, N and P stored in the sediment, we assumed that all the production in the form of rhizomes and roots is stored in the sediment, as is most of the production associated with leaf sheaths, except for eventual losses. These eventual losses were assessed by following weight evolution in time of individual sheaths dated along vertical rhizomes using the technique of lepidochronology (Pergent et al. 1989). Leaf sheath production was estimated as the number of leaves produced per shoot and year (Alcoverro et al 1995, and lepidochronology) multiplied by the average sheath weight (Romero et al. 1992). Rhizome and root annual growth were also estimated using lepidochronology in a similar way as for sheaths.

Biomass and detritus of roots and rhizomes were estimated using samples taken with a diver-held corer (15 cm inner diameter), penetrating $20 \mathrm{~cm}$ into the sediment (Pirc 1983, Romero et al. 1992). Three replicates were taken per depth, and shoot density of each recorded. The sediment was washed off the samples and the plant material sorted into the following fractions as described in Francour (1990): (1) living rhizomes, (2) dead rhizomes, (3) living roots, (4) dead roots and (5) fine, undifferentiated fraction $(0.1$ to $0.8 \mathrm{~cm}$ ). All fractions were then dried and weighed separately, and subsamples kept for elementary analysis.

Carbon and nutrient burial rates were calculated by multiplying sheath, rhizome and root production by the nutrient concentration of the corresponding dead part

Carbon, nitrogen and phosphorus content. All fractions of litter stocks, samples from the litter bags and belowground parts were finely ground. Their $\mathrm{C}$ and $\mathrm{N}$ contents were determined using a Carlo-Erba NA1500 Autoanalyzer. Phosphorus was determined after wet acid digestion by Inductively Coupled Plasma-Atomic Emission Spectrometric (ICP-AES) techniques (Mateo \& Sabaté 1993) 
Statistical methods. From the litter bag experiments and for changes in weight of leaf sheaths and rhizome segments with time, decay rates were computed as the exponent of a single negative exponential function, fitted to the observed data (Olson 1963), and tested against the null hypothesis of zero value. Differences in decay rates between stations ( 5 and $13 \mathrm{~m}$ depth) were assessed using analysis of covariance (weight inside the bags as dependent variable, station as independent variable and time as covariate).

Associated changes with time of $\mathrm{C}, \mathrm{N}$ and $\mathrm{P}$ concentrations were analyzed by regressing the element concentration against time, and testing the null hypothesis of zero-slope.

Student's $t$-test was used to analyze differences in oxygen uptake between fine and coarse litter, and 3 way analysis of variance (ANOVA; independent variables: sampling event, station, incubation temperature) to test the sources of variability for oxygen uptake and nitrogen release rates of coarse detritus.

Seasonality (i.e. differences among sampling events) and differences between stations ( 5 and $13 \mathrm{~m}$ ) in standing leaf litter stocks were tested using 2-way ANOVA, and litter element $(C, N, P)$ concentrations using 2-way MANOVA (multivariate ANOVA). Variability in belowground stocks was analyzed using 3-way ANOVA, with status (living or dead), plant organ (roots and rhizomes) and station (5 and $13 \mathrm{~m}$ ) as independent variables; element ( $\mathrm{C}, \mathrm{N}$ and $\mathrm{P}$ ) concentrations in belowground parts was analyzed using 3-way MANOVA.

Whenever necessary, multiple means comparisons were performed using Tukey's HSD test.

Other estimates. The values of Alcoverro et al. (1995), which were obtained at the same stations and approximately at the same time period to estimate the carbon and nutrient inputs to the leaf compartment, were used. The carbon and nutrient gains of the belowground parts were computed as the production of each organ multiplied by their respective $C, N$ and $P$ concentrations in living parts.

Aerobic respiratory losses (as dry weight and as $\mathrm{N}$ and P) were derived from those obtained on a carbon basis using the average carbon concentration of detritus and the average $\mathrm{C} / \mathrm{N}$ and $\mathrm{C} / \mathrm{P}$ ratios of detritus, respectively.

Nutrient reclamation plus leaching was estimated as the difference between nutrient gains (annual production $\times$ element concentration in living tissues) and overall nutrient losses (annual production $\times$ element concentration in dead tissues).

Finally, we considered that all the leaf litter which is not exported undergoes 'decay' (i.e. as estimated using litter bag experiments), which includes fragmentation, microbial processing and mineralization, among others. In a previous work (Mateo \& Romero 1996), we demonstrated that only $40 \%$, on average, of the weight loss inside the litter bag corresponded to respiratory consumption, the rest being attributable to losses of particulate matter smaller than the mesh size $(0.1 \mathrm{~cm})$, corresponding to both tiny leaf fragments and to micro-flora and micro-fauna elements (very fine litter, VFL)

Hence, we assumed that $60 \%$ of the leaf material which is not exported is transformed into this VFL fraction $(<0.1 \mathrm{~cm})$, the fate of which is uncertain. We transformed this VFL fraction into $C, N$, and $P$ units using average values of $\mathrm{C}, \mathrm{N}$ and $\mathrm{P}$ concentrations in detritus.

\section{RESULTS}

\section{Leaf litter decay}

Considering the period in which the litter bags were submersed, decay proceeded significantly faster ( $\mathrm{p}=$ 0.007 ; Fig 1) at the shallow station than at the deep one: $0.022 \mathrm{~d}^{-1}$ ( \pm 0.0036 , standard error) and $0.019 \mathrm{~d}^{-1}$ $( \pm 0.0042)$ at 5 and $13 \mathrm{~m}$, respectively. On average, half

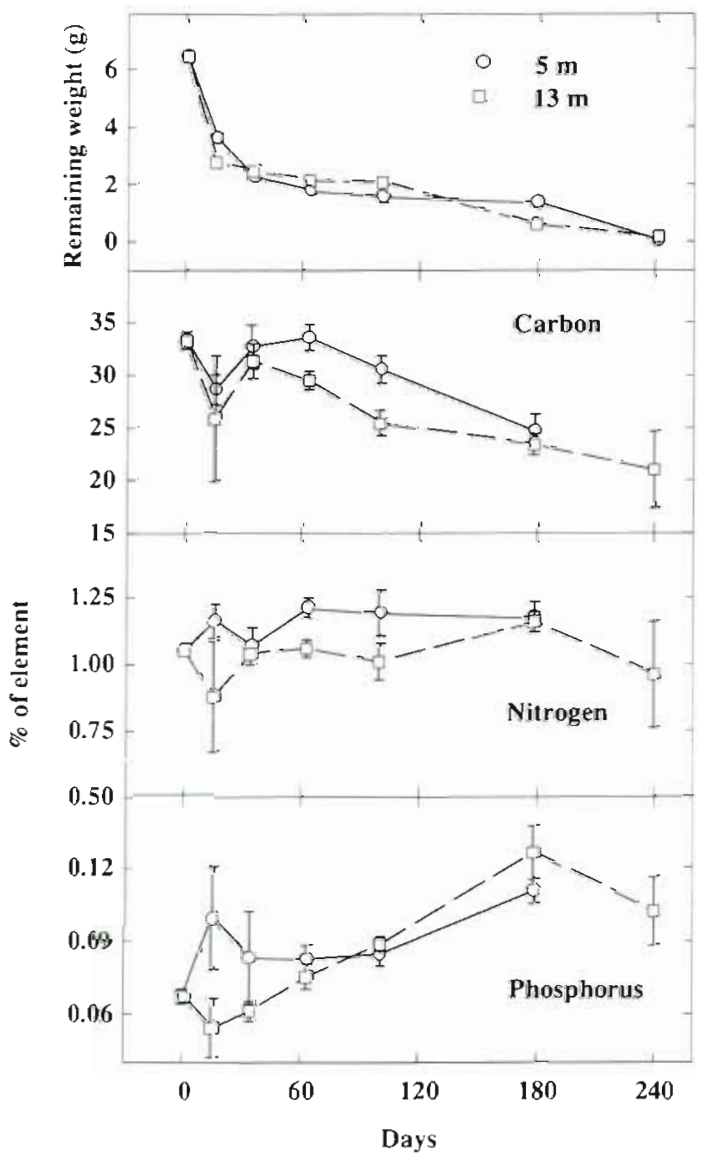

Fig. 1 Results of the litter bag experiment at 5 and $13 \mathrm{~m}$ stations. Error bars represent standard error of the mean $(n=3)$ 


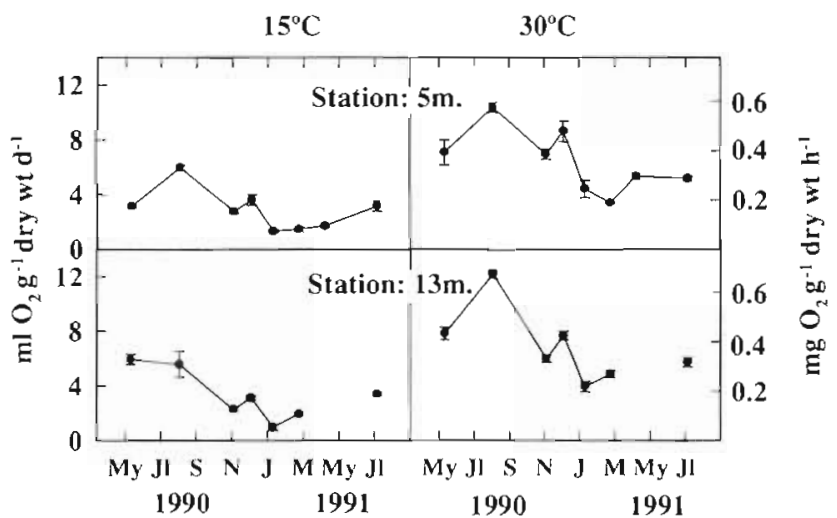

Fig. 2. Posidonia oceanica. Seasonal respiration rates of leaf. detritus incubated at 15 and $30^{\circ} \mathrm{C}$ for both 5 and $13 \mathrm{~m}$ stations. Error bars are standard error of the mean $(n=3)$. At $13 \mathrm{~m}$, the rates corresponding to the April 1997 sampling event were not measured

of the total initial dry weight was lost in about $50 \mathrm{~d}$, and less than $5 \%$ of it remained after $230 \mathrm{~d}$ of incubation. Carbon concentration decreased during the experiment, while nitrogen remained constant and phosphorus increased.

No significant differences in oxygen uptake between fine and coarse litter were found ( $\mathrm{p}=0.864, \mathrm{n}=5)$. Oxygen uptake by coarse detritus ranged from 0.10 to $0.69 \mathrm{mg} \mathrm{O}_{2} \mathrm{~g}^{-1}$ dry wt $\mathrm{h}^{-1}$, increasing with incubation temperature $\left(Q_{10}=1.550 .06, n=23\right)$, and showed a marked seasonality ( $p<0.001$; Fig. 2) following field water temperature pattern (Fig. 3), with maximum values in summer; no significant differences $(p=0.117)$ were found due to the incubation site (5 or $13 \mathrm{~m}$ ). When corrected for field temperature and normalized per unit area (using litter stocks), this resulted in a total in situ respiratory consumption of $57 \mathrm{~g} \mathrm{C} \mathrm{m}^{-2} \mathrm{yr}^{-1}$ at both 5 and $13 \mathrm{~m}$ depth stations, representing 17 and $52 \%$ of the total annual plant primary production.

Leaf detritus incubated in anoxia showed a net nitrogen release, ranging from 0.003 to $0.03 \mathrm{mg} \mathrm{N}_{2} \mathrm{~g}^{-1} \mathrm{dry}$ wt $h^{-1}$. Again the data showed a significant seasonality with maximum values in March ( $\mathrm{p}=0.049$; Fig, 4); val-

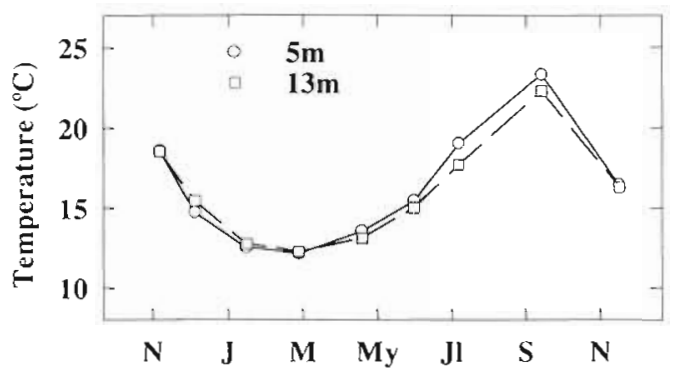

Fig. 3. Water temperature at the studıed stations from Romero (1985)

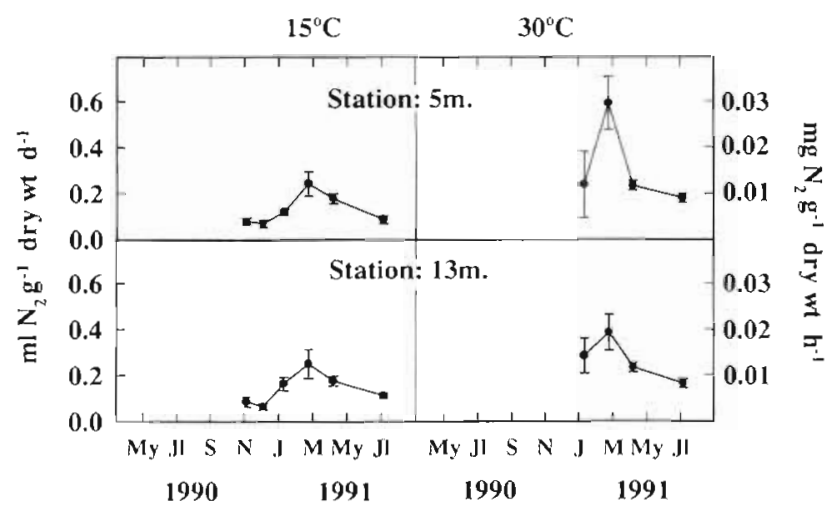

Fig. 4. Posidonia oceanica. Nitrogen released seasonally by leaf detritus incubated at 15 and $30^{\circ} \mathrm{C}$ for both 5 and $13 \mathrm{~m}$ stations. Error bars are standard error of the mean $(\mathrm{n}=3)$

ues from the shallow and deep stations were not statistically different $(p=0.200)$. Nitrogen release increased with incubation temperature (Fig. 4), giving a $Q_{10}=$ $1.57 \pm 0.40(\mathrm{n}=12)$.

\section{Leaf litter export}

Coarse leaf litter stocks per unit area varied seasonally $(\mathrm{p}<0.0001)$, with maximum values $(108.5 \mathrm{~g}$ dry $w \mathrm{t}$ $\mathrm{m}^{-2}$ ) in October and minimum values ( $1.4 \mathrm{~g}$ dry wt $\mathrm{m}^{-2}$ ) in late winter to spring (Fig. 5). The amounts of litter were higher at $5 \mathrm{~m}$ than at $13 \mathrm{~m}(32 \%$ on annual average $\mathrm{p}=0.008$ ). Fine litter stocks per unit area (Fig. 5) followed a similar seasonal pattern, although annually amounting to about twice that of coarse litter. However, only 20 to $40 \%$ of total fine litter was Posidonia oceanica leaf debris.

Carbon, nitrogen and phosphorus concentrations in leaf litter also varied seasonally $(p<0.001)$, peaking in winter. On average, higher concentrations were found at $13 \mathrm{~m}$ than at $5 \mathrm{~m}$ depth for all 3 elements $(\mathrm{p}<0.001$ ).

Annual export rates were strongly seasonal (Table 1), and amounted, on annual average, to $14 \%$ at $5 \mathrm{~m}$ and $6 \%$ at $13 \mathrm{~m}$ of the annual primary production on a dry weight basis ( 18 and $8 \%$ of leaf blade production, respectively); these values strongly depended on the decay rates applied in the model. The sensitivity of the estimation was tested using decay rates in the range plus/minus their standard errors (see above), and litter stock values ranging from those corresponding only to the coarse fraction to those corresponding to coarse + fine fractions (i.e. assuming that origin of the fine fraction was totally allochthonous or totally from Posidonia oceanica, respectively). Final estimations ranged between 13 and $26 \%$ at $5 \mathrm{~m}$ and 4 and $21 \%$ at 13 . Sensitivity was much higher for changes in decay rates than for changes in litter stock estimates. 
Table 1 Posidonia oceanica. Dry weight, carbon, nitrogen and phosphorus exported at 5 and $13 \mathrm{~m}$ stations in the Medes Islands on different days of the year (sampling events) accordinct to the export model (see 'Materials and methods'). Results are expressed as the percentage relative to detritus production. Averages calculated by comparing production to export on an annual basis

\begin{tabular}{|lcccc|}
\hline & Drywt & $\mathrm{C}$ & $\mathrm{N}$ & $\mathrm{P}$ \\
\hline $\mathbf{5} \mathrm{m}$ & & & & \\
21 Feb 89 & 17.5 & 13.1 & 7.7 & 9.3 \\
14 May 89 & 23.5 & 20.2 & 12.8 & 9.7 \\
1 10 Aug 89 & 0 & 0 & 0 & 0 \\
14 Dec 89 & 17.6 & 16.3 & 14.0 & 7.4 \\
16 Feb 90 & 24.4 & 20.9 & 13.8 & 11.9 \\
6 May 90 & 38.7 & 31.4 & 17.4 & 13.0 \\
13 m & & & & \\
21 Feb 89 & 24.2 & 21.1 & 9.1 & 7.6 \\
14 May 89 & 0 & 0 & 0 & 0 \\
10 Aug 89 & 0 & 0 & 0 & 0 \\
14 Dec 89 & 6.7 & 6.6 & 3.5 & 3.5 \\
16 Feb 90 & 0 & 0 & 0 & 0 \\
6 May 90 & 113.0 & 88.5 & 52.8 & 41.6 \\
\hline
\end{tabular}

Table 2. Posidonla oceanica. Dry weight of living and dead organs per unit area $\left(\mathrm{g} \mathrm{m}^{-2}\right)$ at 5 and $13 \mathrm{~m}$ stations. SEM: standard error of the mean $(n=3)$

\begin{tabular}{|lrrrr|}
\hline Fraction & $5 \mathrm{~m}$ & SEM & $13 \mathrm{~m}$ & SEM \\
\hline Living rhizome & 3716 & 768 & 1897 & 202 \\
Dead rhizome & 3314 & 662 & 427 & 117 \\
Living root & 480 & 149 & 294 & 28 \\
Dead root & 426 & 137 & 82 & 15 \\
Fine litter & 247 & 73 & 146 & 50 \\
Total living & 4196 & 2191 & & \\
Total dead & 3987 & 655 & & \\
Total & 8183 & 2846 & & \\
\hline
\end{tabular}

Since significant differences were found in carbon, nitrogen and phosphorus concentrations in leaf litter between depths and sampling events (Fig. 5), seasonal data of litter export (on a dry weight basis) were multiplied by the corresponding element concentration to estimate element export. Results followed a seasonal pattern close to that of total dry matter (Table 1).

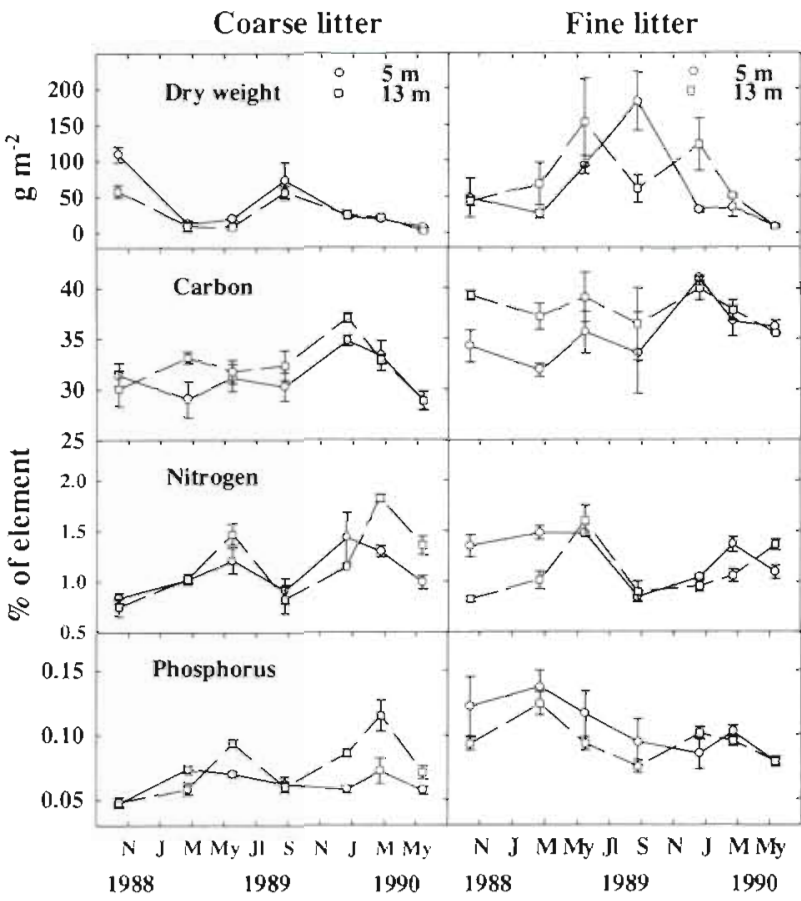

Fig. 5. Posidonia oceanica, Litter stocks dry weight per unit area and carbon, nitrogen and phosphorus for both coarse and fine fractions at the 5 and $13 \mathrm{~m}$ stations. Error bars are standard error of the mean $(\mathrm{n}=3)$

part by depth interaction $(p=0.01)$. At $13 \mathrm{~m}$, dead parts were 3.3 times more abundant than living ones $(p=$ 0.005 ), while at $5 \mathrm{~m}$ no significant differences were observed between dead and living parts.

From these data and those of Fig. 6, annual production of belowground organs per unit area was estimated in 206 and $63 \mathrm{~g}$ dry wt $\mathrm{m}^{-2} \mathrm{yr}^{-1}$ at 5 and $13 \mathrm{~m}$, respectively (Table 3 ).

C, $N$ and $P$ concentrations in belowground parts differed between depths ( $p=0.046$ ) and plant part ( $p<$ $0.001)$. A substantial decrease in nitrogen and phosphorus concentrations were observed in dead material relative to living material (see Table 4); concentrations in dead belowground parts were $23 \%(\mathrm{~N})$ and $34 \%(\mathrm{P})$ lower than those in living ones.

\section{Belowground parts: roots and rhizomes}

The statistical analysis (3-way ANOVA) of belowground stocks indicated that total dry weight (i.e living + detrital parts) per unit area was significantly higher at $5 \mathrm{~m}$ than at $13 \mathrm{~m}$ (Table 2; $\mathrm{p}=0.003$ ), with rhizomes accounting for a major part of these stocks ( $p$ $<0.001$ ). Root contribution increased with depth as indicated by the significant plant-
Table 3. Posidonia oceanica. Annual production of the different parts of the plant system $\left(\mathrm{g} \mathrm{m}^{-2}\right)$. Blade and sheath production according toAlcoverro et al. (1.995)

\begin{tabular}{|lrrrrrrrr|}
\hline & \multicolumn{2}{c}{ Drywt } & \multicolumn{2}{c}{ C } & \multicolumn{2}{c}{ N } & \multicolumn{2}{c|}{ P } \\
& $5 \mathrm{~m}$ & $13 \mathrm{~m}$ & $5 \mathrm{~m}$ & $13 \mathrm{~m}$ & $5 \mathrm{~m}$ & $13 \mathrm{~m}$ & $5 \mathrm{~m}$ & $13 \mathrm{~m}$ \\
\hline Blades & 620 & 219 & 252 & 87 & 11.8 & 5.9 & 0.930 & 0.350 \\
Sheaths & 146 & 37 & 51 & 12 & 1.7 & 0.6 & 0.234 & 0.070 \\
Rhizomes & 37 & 15 & 15 & 6 & 0.3 & 0.2 & 0.014 & 0.007 \\
Roots & 23 & 11 & 10 & 5 & 0.1 & 0.1 & 0.011 & 0.008 \\
Total & 826 & 282 & 328 & 110 & 13.9 & 6.8 & 1.188 & 0.435 \\
\hline
\end{tabular}




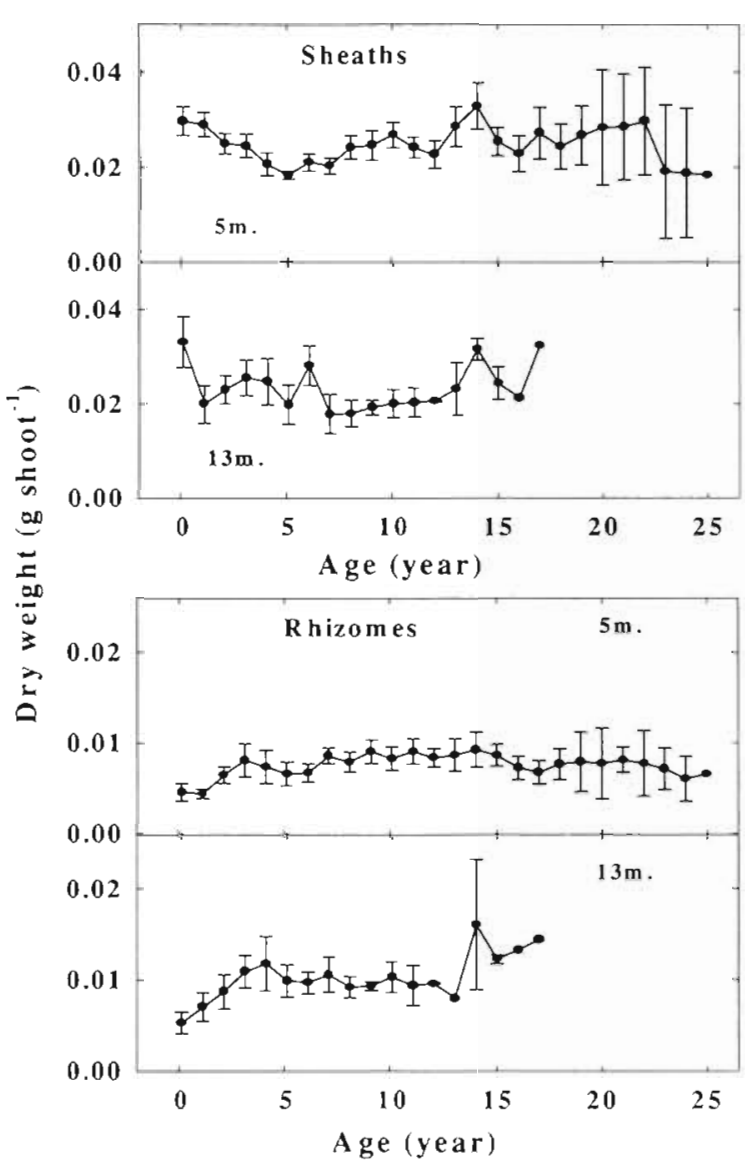

Fig. 6. Posidonia oceanica. Leaf sheath and rhizome weight (per shoot) evolution with age. Error bars are standard error of the mean ( $n=12$ in the majority of cases; in the rest, except for the oldest sample where $n=1, n \geq 3$ )

No weight loss with time was detected in leaf sheaths or rhizomes at both 5 and $13 \mathrm{~m}(\mathrm{p}=0.100$; Fig, 6). Carbon concentration remained constant with time. Nitrogen and phosphorus concentration in leaf

Table 4. Posidonia oceanica. Carbon and nutnent content of the different parts (living and dead) of the plant at both 5 and $13 \mathrm{~m}$ stations. Values are in \% of element relative to dry weight. Standard error of the mean was always $<10 \%$ of the mean $(\mathrm{n}>3)$

\begin{tabular}{|lcccccc|}
\hline & \multicolumn{2}{c}{$\mathrm{C}$} & \multicolumn{2}{c}{$\mathrm{N}$} & \multicolumn{2}{c|}{$\mathrm{P}$} \\
& $5 \mathrm{~m}$ & $13 \mathrm{~m}$ & $5 \mathrm{~m}$ & $13 \mathrm{~m}$ & $5 \mathrm{~m}$ & $13 \mathrm{~m}$ \\
\hline Young leaves & 38.4 & 38.3 & 2.03 & 2.17 & 0.160 & 0.160 \\
Old leaves & 36.1 & 36.8 & 1.99 & 2.41 & 0.140 & 0.160 \\
Leaf litter (coarse) & 31.1 & 32.0 & 1.03 & 1.18 & 0.062 & 0.072 \\
Leaf litter (fine) & 35.4 & 37.1 & 1.20 & 1.13 & 0.104 & 0.095 \\
Living rhizome & 38.4 & 37.1 & 0.82 & 0.89 & 0.046 & 0.043 \\
Dead rhizome & 41.2 & 38.3 & 0.68 & 0.65 & 0.033 & 0.034 \\
Living roots & 40.9 & 40.9 & 0.58 & 0.80 & 0.045 & 0.072 \\
Dead roots & 44.5 & 43.8 & 0.51 & 0.52 & 0.032 & 0.032 \\
Fine belowground detritus & 41.5 & 39.0 & 0.93 & 0.95 & 0.068 & 0.105 \\
\hline
\end{tabular}

sheaths were high during the first year after leaf fall, with values close to those found in living leaf sheaths, declined for 3 to $4 \mathrm{yr}$ and remained constant afterwards, with values close to those in sheaths attached to dead rhizomes (Fig. 7). A similar pattern was found in the rhizomes.

\section{Budgets}

The terms of the balance obtained did not show important differences between the 2 stations studied except for carbon losses through litter respiration, which were (relative to total production at the considered station) 3 times higher at $13 \mathrm{~m}$. The values for the undetermined fraction estimated for dry weight and carbon contrast with those for nutrients (Table 5), evidencing the importance of reclamation phenomena associated with the latter.

\section{DISCUSSION}

Export rates are lower than those found in previous works: 13 to $26 \%$ at $5 \mathrm{~m}, 4$ to $21 \%$ at $13 \mathrm{~m}$, compared to 47 to $56 \%$ in Ischia meadow, Naples, Italy (values relative to blade production; Romero et al. 1992, Pergent et al. 1994). Losses through export phenomena are controlled by litter production lamount and timing), intensity and time distribution of wave action, and decay rates. Since the ratios between primary production and standing litter stocks of the meadows in the Medes Islands (Romero et al. 1992, Alcoverro et a]. 1995) and Ischia Islands (Buia et al. 1992) are of the same order, differences in leaf decay rates between these 2 meadows $\left(0.019\right.$ to $0.022 \mathrm{~d}^{-1}$ at Medes Islands, 0.003 to $0.006 \mathrm{~d}^{-1}$ at Ischia Islands) should account for the differences observed in export rates. To test this hypothesis, we evaluated the export rates in the Medes Islands using the decay rates from Ischia, and we obtained values between 50 and $56 \%$, close to those from the Ischia meadow (47 to $56 \%$; Romero et al. 1992)

Leaf litter decay rates reported in the literature are in the range 0.0007 to $0.1 \mathrm{~d}^{-1}$ (Harrison 1989); this large range would result in export rates from near 0 to $100 \%$ if applied to our data of litter production and litter stocks. Previous evidence leads to the conclusion that decay rates may be a major control of export rates. Internal nutrients, i.e. $\mathrm{N}$ and $\mathrm{P}$ concentrations in leaves and detritus, have been proposed as factors determining, at least within 


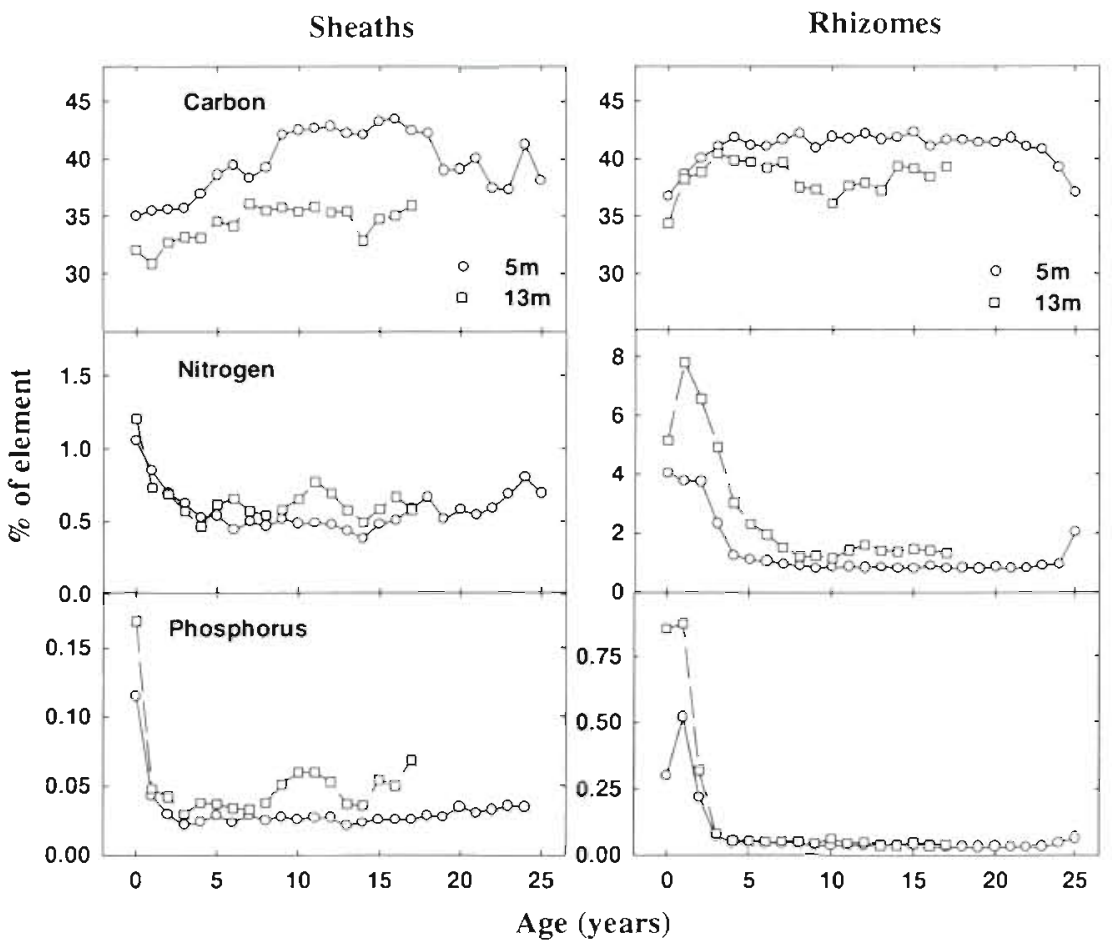

Fig. 7 Posidonia oceanica. Changes with age of carbon, nitrogen and phosphorus content of leaf sheaths and rhizomes for the 5 and $13 \mathrm{~m}$ stations
Table 5. Posidonia oceanica. Dry weight, carbon and nutrient budget in the Medes Islands $\left(\mathrm{g} \mathrm{m}^{-2} \mathrm{yr}^{-1}\right)$. Values relative to annual production are given in parentheses. Terms explained in text. Values siven for denitrification should be considered as potential and merely indicativo. The undetermined fraction of the budget is a consequence of the unknown fate of the very fine fraction $(<1 \mathrm{~mm})$ originated during leat decay (see text)

\begin{tabular}{|c|c|c|c|c|}
\hline & Dry wt & C & $N$ & $P$ \\
\hline \multicolumn{5}{|l|}{$5 \mathrm{~m}$} \\
\hline Production & $826(100)$ & $328(100)$ & $139(100)$ & $1.188(100)$ \\
\hline \multicolumn{5}{|l|}{ Fate } \\
\hline Export & $112(14)$ & $24(7)$ & $1.2(9)$ & $0.070(6)$ \\
\hline Burial & $206(25)$ & $84(26)$ & $1.1(8)$ & $0.060(5)$ \\
\hline \multicolumn{5}{|l|}{ Reclamation } \\
\hline Leaves & & & $6.2(45)$ & $0.545(46)$ \\
\hline Belowground & & & $0.9(6)$ & $0372(31)$ \\
\hline \multicolumn{5}{|c|}{ Respiratory consumption } \\
\hline Aerobic & $143(17)$ & $57(17)$ & $1.9(14)$ & $0.114(10)$ \\
\hline Anaerobic & $9(1)$ & $4(1)$ & $2.2(16)$ & \\
\hline Undetermined fraction & $356(48)$ & $159(49)$ & $0.4(3)$ & $0.027(2)$ \\
\hline \multicolumn{5}{|l|}{$13 \mathrm{~m}$} \\
\hline Production & $282(100)$ & $110(100)$ & $6.8(100)$ & $0.435(100)$ \\
\hline \multicolumn{5}{|l|}{ Fate } \\
\hline Export & $18(6)$ & $5(5)$ & $0.2(3)$ & $0.010(2)$ \\
\hline Burial & $63(22)$ & $24(21)$ & $0.5(7)$ & $0.027(6)$ \\
\hline \multicolumn{5}{|l|}{ Reclamation } \\
\hline Leaves & & & $3.1(46)$ & $0.192\{44\}$ \\
\hline Belowground & & & $0.4(6)$ & $0.081\{19\}$ \\
\hline \multicolumn{5}{|c|}{ Respiratory consumption } \\
\hline Aerobic & $143(51)$ & $57(52)$ & $1.1(16)$ & $0.118(27)$ \\
\hline Anaerobic & $11(4)$ & $5(5)$ & $1.3(19)$ & \\
\hline Undetermined fraction & $47(17)$ & $19(17)$ & $0.2(3)$ & $0.007(2)$ \\
\hline
\end{tabular}

species, decay rates (Wiecler \& Lang 1982); we conclude that under conditions of high nutrient availability (and hence of higher nutrient content in plant tissue), in a constant wave action regime, the relative importance of export and decay with respect to each other will be shifted towards the latter. Our data are consistent with this contention, as Posidonia oceanica leaves from Ischia have lower content of $\mathrm{N}$ and $\mathrm{P}$ than those from the Medes Islands (1.8 and 2.4 times lower, respectively). Wave action plays also a major role as generating variability in export rates (e.g. along the bathymetric axis). If we compute export values for the shallow and the deep zones using the same decay rate $\left(k=0.0205 \mathrm{~d}^{-1}\right.$, average of the values at 5 and $13 \mathrm{~m}$ ), we obtain estimations of 22 and $5 \%$ (relative to the leaf blade production on a dry weight basis) for 5 and $13 \mathrm{~m}$, respectively.

Differences in export rates between 5 and $13 \mathrm{~m}$ should be attributed to differences in wave action, which attenuates exponentially with depth (Gambi et al. 1989). Leaf litter export probably occurs in discontinuous episodes associated with storms; the frequency of storms generating significant turbulence near the sea. 
bottom is lower at 13 than at $5 \mathrm{~m}$, and thus the time between consecutive export episodes is longer at $13 \mathrm{~m}$ than at $5 \mathrm{~m}$, so decay can proceed for a longer time period. Therefore, we can state that increased wave action interrupts the in situ decay process, and increases the relative importance of export with respect to decay

Given the low export values, the most important pathway of carbon losses concerning the leaf compartment is decay, as derived from weight loss inside the litter bags. Such weight loss includes several processes, which fall into 2 main categories: respiratory consumption and particulate matter losses through the mesh. Respiratory consumption of leaf detritus accounts for 17 to $52 \%$ of total primary production on a carbon basis (at 5 and $13 \mathrm{~m}$, respectively; see Table 5) or 23 to $65 \%$ of leaf blade production (see Table 3 ), and the rest corresponds to particulate losses of very fine litter (less than $1 \mathrm{~mm}$ in size), which include tiny leaf debris as well as organic carbon incorporated into decomposer biomass (bacteria, fungi, protozoa). Comparing these data of respiratory consumption to those of leaf production and export (Table 5), we conclude that this very fine litter fraction amounts to 159 and 19 $\mathrm{g} \mathrm{C} \mathrm{m} \mathrm{mrr}^{-1}$ at 5 and $13 \mathrm{~m}$, respectively, the fate of which is undetermined. An unknown proportion of it will be incorporated into the sediment (organic content of the sediment: $4.1 \pm 0.7 \%$; López et al. 1995), and consumed there by bacteria, meiofauna or macrosedimentivores (Abada-Guerroui \& Willsie 1984, Coulon \& Jangoux 1993), or buried (Romero et al. 1994). The rest will be incorporated into the seston and consumed or exported in turn.

Burial in belowground organs (Figs. $6 \& 7$, Table 5) is similar to that reported for the same species in other works, as derived from values of standing biomass (Pirc 1983, Francour 1990, Sánchez-Lizaso 1993) or rhizome growth (Romero et al. 1992, Sánchez-Lizaso 1993, Pergent et al. 1994), Our data are higher than those presented in a previous paper (Mateo et al. 1997), but this is due to the different time scales involved in each work (decades in the present one, millennia in Mateo et al. 1997)

In summary, carbon losses from the plant occur through leaf fall ( 75 and $78 \%$ at 5 and $13 \mathrm{~m}$, respectively) and rhizome, leaf sheath and root accumulation (25 and $22 \%$ ). Leaf detritus has 3 main fates: export. respiratory consumption or transformation into very fine detritus. The export contribution to carbon losses is relatively small in the studied meadow (14 and 6\% of total primary production). Respiratory consumption accounts for an important part of C losses (17 and $51 \%$, or 18 and $55 \%$ if we also consider anaerobic respiration in detritus). The losses in the form of detritus smaller than $1 \mathrm{~mm}$ is substantial, amounting to 43 and
$17 \%$ of total primary production; the final fate of this very fine fraction (consumption, export or burial) is unknown, and, hence, constitutes an undetermined portion of the proposed budget. Patterns of carbon losses differ between 5 and 13 m depth mostly regarding export rates and respiratory consumption, and these differences may be explained by the variability of wave action along a depth gradient.

Only a part (at most 43 and $17 \%$ at 5 and $13 \mathrm{~m}$, respectively, but probably less) of the total plant production may be used to fuel the trophic chains of the seagrass ecosystem. This contrasts with the species richness (Mazzella et al. 1992) of the ecosystem and with a high carbon demand in the sediment (López et al. 1995), caused mainly by bacterial metabolism and production, which in turn feeds the rich infaunal assemblages. Even if we lack reliable data to incorporate this carbon demand into our budget, it seems reasonable that most of the trophic chains within the ecosystem should be supported by other sources of organic carbon. For example, most of the mobile fauna of the leaf stratum is supported by epiphyte production (Mazzella et al. 1992), which can reach 10 to $100 \mathrm{~g} \mathrm{C}$ $\mathrm{m}^{-2} \mathrm{yr}^{-1}$, while the fauna of the sediment is probably supported in part by the epiphytes fallen from the leaves, by the litter fraction smaller than $1 \mathrm{~mm}$ (very fine litter fraction) and by seston sedimentation which can be as high as 65 to $123 \mathrm{~g} \mathrm{C} \mathrm{m}^{-2} \mathrm{yr}^{-1}$ (Jacques 1973, Sournia 1973, Béthoux \& Copin-Montégut 1986) if we assume that the final destination of all the phytoplankton in the overlying water column is the sediment. This is in agreement with findings based on stable isotopic ratios (Dauby 1989).

Total nutrient losses for the ecosystem (exported + buried + potential anaerobic $N$ respiration; Table 5) are in the range of 17 to 36 and 10 to $32 \%$ for $N$ and 11 to 13 and 8 to $10 \%$ for $P$ (5 and $13 \mathrm{~m}$, respectively, relative to total annual nutrient requirements). In the case of $\mathrm{N}$, the main source of the uncertainty is the lack of knowledge about the actual denitrification rate, considering that the observed ones are estimates of potential (i.e. maximum) rates. In the case of $P$, the uncertainty originates from the unknown fate of the very fine litter fraction. These losses are generally lower than those found for carbon or dry weight, due to the differences in nutrient content between living and dead tissues (Table 4). Alcoverro (1995) found great differences between young and old leaves, indicating nutrient reclamation (Pedersen \& Borum 1992); in addition, significant differences also exist in $\mathrm{N}$ and $\mathrm{P}$ concentrations between senescent leaves (see Fig. 1, Day 0) and standing litter, showing the existence of a leaching process immediately after leaf abscission (Table 4).

In the case of belowground organs, there is also a sharp decrease in nutrient concentration observed in 
leaf sheaths $(55 \%$ decrease in $\mathrm{N}, 70 \%$ in $\mathrm{P}$ ) and rhizomes ( 80 and $90 \%$ of decrease in $N$ and $P$, respectively; Fig. 7 ) during the 2 to 3 yr following leaf abscission, which may be again the result of leaching or of nutrient reclamation by younger parts.

This means that effective nutrient losses for the system, through litter export or burial in the sediment, are greatly reduced with respect to potential ones. Losses of $P$, the estimates of which are not affected by the uncertainty associated with denitrification, are relatively small ( 8 to $13 \%$ ), and most of the $\mathrm{P}$ recycles within the plant ( $\mathrm{P}$ reclamation) or within the system (in situ leaching or remineralization). These losses represent the minimum amount of $P$ requirements that should be met by import (i.e. advection, or remineralization of allochthonous organic matter such as seston sedimentation). Thus, the ratio of new production to total production ( $f$ ratio; Dugdale \& Goering 1967. Epply \& Peterson 1979) in the Posidonia oceanica ecosystem studied is, concerning $P$, close to 0.1 . In the case of $N$, this ratio will be substantially higher if part of the potential denitrification is effectively taking place. The studied seagrass meadow should thus be considered as a relatively efficient system with regard to nutrient recycling

\section{LITERATURE CITED}

Abada-Guerroui H, Willsie A (1984) Résultats préliminaires de l'étude des constituants chimiques et faunistiques d'une matte morte d'herbier à Posidonia oceanica à Fos et sur la Côte Bleue (Bouches-du-Rhône, France). In: Boudouresque CF, Grissac AJD, Olivier J (eds) Proc 1st Int Workshop on Posidonia oceanica beds, Marseille, France. GIS Posidonie 1:389-398

Alcoverro T (1995) Production ecology of the Mediterranean seagrass Posidonia oceanica (L.) Delile. PhD thesis, Barcelona University, Barcelona

Alcoverro T, Duarte CM, Romero J (1995) Annual growth dynamics of Posidonia oceanica: contribution of largescale versus local factors to seasonality. Mar Ecol Prog Ser $120: 203-210$

Alcoverro T, Duarte CM, Romero J (1997) Posidonia oceanica epiphytes: the influence of herbivores. Aquat Bot 56: 93-104

Benner R, K'nees $E_{1}$ Hodson RE (1988) Carbon coversion eificiency for bacterial growth on lignocellulose: implications for detritus-based food webs. Limnol Oceanogr 33: $1514-1526$

Béthoux JP, Copin-Montégut G (1986) Biological fixation of atmospheric nitrogen in the Mediterranean Sea. Limnol Oceanogr 31:1353-1358

Buia MC, Zupo V, Mazzella L (1992) Primary production and growth dynamics of Posidonia oceanica. PSZN I: Mar Ecol $13(1): 1-15$

Cebrián J, Duarte CM, Marbà N, Enríquez S, Gallegos M. Olesen B (1996) Herbivory on Posidonia oceanica: magnitude and variability in the Spanish Mediterranean. Mar Ecol Prog Ser 130:147-155

Coulon P, Jangoux M (1993) Feeding rate and sediment reworking by the holothuroid Holothuna tubulosa (Echınodermata) in a Mediterranean seagrass bed of Ischia Island, Italy. Mar Ecol Prog Ser 92:201-204

Dauby P (1989) The stable carbon isotope ratios in benthic food webs of the Gulf of Calvi, Corsica. Cont Shelf Res 9: 181-195

Duarte CM (1989) Temporal biomass variability and production/biomass relationships of seagrass communities. Mar Ecol Prog Ser 51:269-276

Dugdale RC, Gorring JJ (1967) Uptake of new and regenerated forms of nitrogen in primary productivity. Limnol Oceanogr 12:196-206

Elliot JW, Davison W (1975) Energy equivalents of oxygen consumption in animal energetics. Oecologia (Berl) 19:195-201

Eppley RW, Peterson BJ (1979) Particulate organic matter flux and planktonic new production in the deep ocean. Nature 282:677-680

Francour P (1990) Dynamique de l'écosystème à Posidonia oceanica dans le Parc National de Port-Cros. Analyse des compartıments matte, litière, faune vagile, échinodermes et poissons. Thèse doctorale, Univ Aix-Marseille II

Froelich PN, Klinkhammer GP, Bender ML, Luedtke NA, Heath GR, Cullen D, Dauphin P (1979) Early oxidation of ordanic matter in pelagic sediments of the eastern equatoIidl Atlantic: suboxic diagenesis. Geochim Cosmochim Lcta 43:1075-1090

Gambi MC, Buia MC, Scardi M (1989) Estimates of water movement in Posidonia oceanica beds: a first approach. In. Boudouresque CF, Meisnez A, Fresi E, Gravez $V$ (eds) Proc 2nd Int Workshop on Posidonia oceanica Beds، Ischia, Italy. GIS Posidonie 2:175-179

Harrison PG (1989) Detrital processing in seagrass systems: a review of factors affecting decay rates, remineralization and detritivory. Aquat Bot 23:263-288

Hemminga MA, Harrison PG, van Lent $F(1991)$ The balance of nutrient losses and gains in seagrass meadows. Mar Ecol Prog Ser 71:85-96

Jaques G, Minas HJ, Minas M, Nival P (1973) Influence des conditions hivernales sur le production phyto et zooplanctoniques. Mar Biol 23:251-265

Jørgensen BB, Sørensen J (1985) Seasonal cycles of $\mathrm{O}_{2}, \mathrm{NO}_{3}$ and $\mathrm{SO}_{4}{ }^{2-}$ reduction in estuarine sediments: the significance of an $\mathrm{NO}_{3}{ }^{-}$reduction max.mum in spring. Mar Ecol Prog Ser 24:65-74

Kaplan W, Valiela I, Teal JM (1979) Denitrification an a salt marsh ecosystemi. Limnol Oceanogr 24:726-734

Lopez NI, Duarte CM, Vallespinós F, Romero J, Alcoverro T (1995) Bacterial actıvity in seagrass (Posidonia oceanica) sediments. J Exp Mar Biol Ecol 187:39-49

Mann KH (1988) Production and use of detritus in various freshwater, estuarine, and coastal marine ecosystems. Limnol Oceanogr 33:910-930

Mateo MA, Romero J (1996) Evaluating seagrass leaf litter decomposition: an experimental comparison between litter-bag and oxygen-uptake methods. J Exp Mar Bıol Ecol. 202:97-1.06

Mateo MA, Romero J, Pérez M, Littler MM, Littler DS (1997) Dynamics of millenary organic deposits resulting from the growth of the Mediterranean seagrass Posidonia oceanica. Estuar Coast Shelf Sci 44:103-110

Mateo MA, Sabaté S (1993) Wet digestion of vegetal tissue using a domestic microwave oven. Anal Chirn Acta 279: $273-279$

Mazzella L, Buia MC, Gambi MC, Lorenti M, Russo GF, Scipione MB, Zupo V (1992) Plant-animal trophic relationships in the Posidonia oceanica ecosystem of the Mediterranean Sea: a review. In: John DM, Hawkins SJ, Price JH leds) 
Plant-animal interactions in the marine benthos. Clarendon Press, Oxford, p 165-187

Nienhuis PH, Groenendijk AM (1986) Consumption of ee]grass (Zostera marna) by birds and invertebrates: an annual budget. Mar Ecol Prog Ser 29:29-35

Olson JS (1963) Energy storage and the balance of producers and decomposers in ecological systems. Ecology 44(2) 322-331

Ott J, Maurer L (1977) Strategies of energy transfer from marine macrophytes to consumer levels: the Posidonıa oceanica example. In: Keegan B (ed) Biology of benthic organisms. Pergamon Press, Oxford, p 493-502

Pedersen MF, Borum J (1992) Nitrogen dynamics of eelgrass Zostera marina during a late summer period of high growth and low nutrient availability. Mar Ecol Prog Ser 80: $65-73$

Pergent G, Boudouresque CF, Crouzet A, Meinesz A (1989) Cyclic changes along Posidonia oceanica rhizomes (lepidochronology): present state and perspectives. PSZN [ Mar Ecol 10:221-230

Pergent G, Pergent-Martini C (1991) Leaf renewal cycle and primary production of Posidonia oceanica in the bay of Lacco Ameno (Ischia, Italy) using lepıdochronological analysis. Aquat Bot 42:49-66

Pergent G, Romero J, Pergent-Martini C, Mateo MA, Boudouresque CF (1994) Primary production, stocks and fluxes in the Mediterranean seagrass Posidonia oceanica. Mar Ecol Prog Ser 106:139-146

Pirc H (1983) Belowground biomass of Posidonia oceanica (L.) Delile and its importance to the growth dynamics. In: Proc Int Symp on Aquatic Macrophytes, Nijmegen, The Netherlands, p 77-81

Romero J (1985) Estudio ecologico de las fanerôgamas marinas de la costa catalana: producción primaria de Posidonia oceanica (L.) Delile en las Islas Medes. PhD thesis, Barcelona University

This article was submitted to the editor
Romero J (1989) Seasonal pattern of Posidonia oceanica production: growth, age and renewal of leaves. In: Boudouresque C.F, Meinesz A, Fresi E, Gravez V (eds) Proc 1st lnt Workshop on Posidonia Beds, Marseille, France. GIS Posidonie 1:63-68

Romero J, Pergent G, Pergent-Martini C, Mateo MA, Regnier $C$ (1992) The detritic compartment in a Posidonia oceanica meadow: litter features, decomposition rates and mineral stocks. PSZN l: Mar Ecol 13(1):69-83

Romero J, Pérez M, Mateo MA Sala E (1994) The belowground organs of the Mediterranean seagrass Posidonia oceanica as a biogeochemical sink. Aquat Bol 47:13-19

Sánchez-Lizaso JL (1993) Estudio de la pradera de Posidonia oceanica (L.) Delile de la reseva marina de Tabarca (Alicante): Fenología y producción primaria. PhD thesis, Alicante University, Alicante

Sournia A (1973) La production primaire planctonique en Méditerranée. Essai et mise à jour. Bull Etud Comm Méditerr (No. Spéc 5):1-128

Thayer GW, Biorndal KA, Ogden JC, Williams SL, Zieman JC (1984) The role of large herbivores in seagrass communities. Estuaries 7:351-376

Valiela I (1984) Marine ecological processes. Springer-Verlag, New York

Wieder RK, Lang GE (1982) A critique of the analytical methods used in examining decomposition data obtained from litter bags. Ecology 63:1636-1642

Zieman JC, Thayer GW, Roblee MB, Zieman RT (1979) Production and export of seagrasses from a tropical bay. In: Livingston RJ (ed) Ecological processes in coastal and marne systems. Plenum Press, New York, p 21-33

Zupo V. Fresi E (1984) A study on the food web of the Posidonia oceanica ecosystem: analysis of the gut content of echinoderms. In: Boudouresque CF, Grissac AJD, Olivier J (eds) Proc 1st Int Workshop on Posidonia oceanica Beds, Marseille, France. GIS Posidonie 1:373-379

Manuscript furst received: March 22, 1996 Revised version accepted: March 3, 1997 